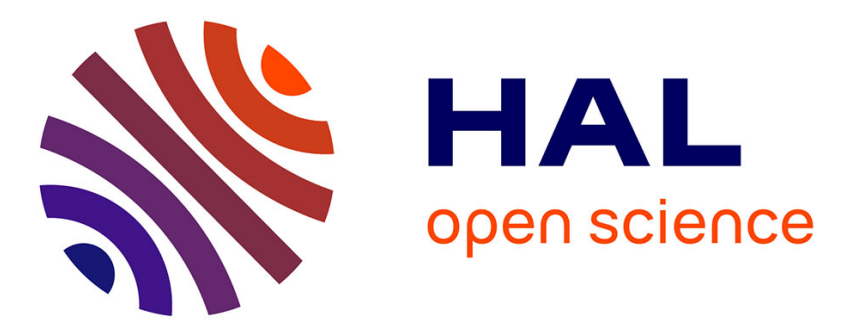

\title{
Neuroblastoma and tooth abnormalities: a common history?
}

\author{
Caroline Abadie, Bénédicte Lechaix, Virginie Gandemer, Martine \\ Bonnaure-Mallet
}

\section{- To cite this version:}

Caroline Abadie, Bénédicte Lechaix, Virginie Gandemer, Martine Bonnaure-Mallet. Neuroblastoma and tooth abnormalities: a common history?. Oral Oncology, 2013, 49 (4), pp.e11-3. 10.1016/j.oraloncology.2012.12.013 . inserm-00825411

\section{HAL Id: inserm-00825411 https://www.hal.inserm.fr/inserm-00825411}

Submitted on 23 May 2013

HAL is a multi-disciplinary open access archive for the deposit and dissemination of scientific research documents, whether they are published or not. The documents may come from teaching and research institutions in France or abroad, or from public or private research centers.
L'archive ouverte pluridisciplinaire HAL, est destinée au dépôt et à la diffusion de documents scientifiques de niveau recherche, publiés ou non, émanant des établissements d'enseignement et de recherche français ou étrangers, des laboratoires publics ou privés. 


\title{
Neuroblastoma and tooth abnormalities: a common history?
}

\author{
ABADIE Caroline ${ }^{1}$, LECHAIX Bénédicte ${ }^{2}$, GANDEMER Virginie ${ }^{3}$, \\ BONNAURE-MALLET Martine ${ }^{4}$
}

${ }^{1}$ Service de Génétique Médicale, Oncogénétique, CHU Hôpital Sud, Rennes

${ }^{2}$ UFR d'Odontologie, Université de Rennes 1, Université Européenne de Bretagne,

Rennes

${ }^{3}$ Service d'Oncopédiatrie, CHU Hôpital Sud, Rennes

${ }^{4}$ Equipe Microbiologie, UPRES-EA 1254, IFR GFAS 140, Faculté des Sciences Pharmaceutiques et Biologiques, Université de Rennes 1, Université Européenne de Bretagne, Rennes and CHU, Rennes

Short title: neuroblastoma and teeth

Keywords : neuroblastoma, children, teeth, agenesia, oligodontia

Corresponding author: martine.bonnaure@univ-rennes1.fr 


\section{Neuroblastoma and tooth abnormalities: a common history?}

Neuroblastoma, a malignant tumor of the sympathetic nervous system and the most common extracranial solid tumor in childhood, arises from embryonic neural crest cells. Tooth development begins before birth and continues for 12-14 years with the development of the third molar for several years. Abnormal events that occur during odontogenesis give permanent damage. Whereas the impact of multimodal therapy including radiotherapy and chemotherapy is major in tooth development defects ${ }^{1}$ we suggested that the particular association between neuroblastoma and the occurence of missing teeth is not necessary due to treatment effects but considered the hypothesis of a common underlying genetic defect because of common cell origin.

Dental data were obtained via medical or dental records for 12 patients treated for neuroblastoma at the Pediatric Oncology and Hematology department in the University Hospital of Rennes (France). Panoramic radiographs could be effectively performed in seven patients. We observed dental disturbances in 8 patients including oligodontia for five (table 1). For 4 of them, we note the MYCN amplification in neuroblastoma cells. All but one were treated with one or more chemotherapeutic agents incriminated in tooth defect development and underwent a transplant. It would be attractive to incriminate the treatment effects as the cause of the dental abnormalities onset, because of the young age at NBL diagnosis contemporary to the most active dental development period. Furthermore, their treatment consists in multimodal therapy and used drugs commonly associated with dental defects in rodent experimentations ${ }^{2,3}$. In our study, oligodontia was also present in children under 3 years but this finding is not surprising because of the neuroblastoma median age of 2 . Also we note the occurrence of both crown and eruption dental abnormalities in one patient (patient 11) treated with chemotherapy and autologous stem cell transplantation but at age 10. 
While prevalence of dental agenesis is around $5 \%$ in general population ${ }^{4}$, a recent study found a prevalence of $16.2 \%$ missing teeth in childhood cancer survivors treated from 0 to $7^{5}$. Even if chemotherapy and total bone irradiation radiotherapy are likely to be etiological factors, it cannot be ruled out that regarding neuroblastoma, a developmental etiology could be considered. So intringuing, four of five patients with tooth agenesis presented a MYCN gene amplification. The proto-oncogene $M Y C N$ is mainly expressed during neural development ${ }^{6}$ and frequently amplified in advanced-stage neuroblastoma associated with poor prognosis. $M Y C N$ might stimulate neuroblastoma cell proliferation by inhibiting negative regulators of the Wnt signaling ${ }^{7}$. Furthermore, while germline mutations in the transcription factor $\mathrm{PHOX} 2 \mathrm{~B}$ gene have been reported in sporadic and familiar forms of neuroblastoma ${ }^{8,9}$, the MSX1 target is known to be associated with tooth agenesis ${ }^{10,11}$. Interestingly, MSX1, an important homeobox gene in embryonic neural crest development, was shown to be down regulated after inducible expression of $\mathrm{PHOX} 2 \mathrm{~B}^{12}$. This PHOX2B target is involved in both embryonic developmental pathways Delta-Notch and Wnt ${ }^{12,}{ }^{13}$. Whereas links between cancer predisposition and dental abnormalities are well known for adulthood cancers involving disruption of the Wnt signalling (germline AXIN2 mutations, Gardner syndrome), we could emphasize that a dysregulation of the Wnt signaling pathway could take part in alteration of dental genesis and neuroblastoma tumorigenesis.

\section{ACKNOWLEDGEMENTS}

The authors thank Céline Allaire for editorial assistance. 


\section{REFERENCES}

1. Holtta P, Alaluusua S, Saarinen-Pihkala UM, Peltola J, Hovi L. Agenesis and microdontia of permanent teeth as late adverse effects after stem cell transplantation in young children. Cancer 2005;103(1):181-190.

2. Avsar A, Elli M, Darka O, Pinarli G. Long-term effects of chemotherapy on caries formation, dental development, and salivary factors in childhood cancer survivors. Oral Surg Oral Med Oral Pathol Oral Radiol Endod 2007;104(6):781-789.

3. Maciel JC, de Castro CG, Jr., Brunetto AL, Di Leone LP, da Silveira HE. Oral health and dental anomalies in patients treated for leukemia in childhood and adolescence. Pediatr Blood Cancer 2009;53(3):361-365.

4. Thierry M, Granat J, Vermelin L. Les agénésies dentaires : origine, évolution et orientations thérapeutiques. Int Orthod 2007;5:163-182.

5. Cubukcu CE, Sevinir B, Ercan I. Disturbed dental development of permanent teeth in children with solid tumors and lymphomas. Pediatr Blood Cancer 2012;58(1):80-84.

6. Yamada S, Ikeda MA, Eto K. Differential expression of c-myc and N-myc during oral organogenesis of the mouse embryo. Dev Growth Differ 1992;34:239-251.

7. Koppen A, Ait-Aissa R, Hopman S, Koster J, Haneveld F, Versteeg R, et al. Dickkopf-1 is down-regulated by MYCN and inhibits neuroblastoma cell proliferation. Cancer Lett 2007;256(2):218-228.

8. Trochet D, O'Brien LM, Gozal D, Trang H, Nordenskjold A, Laudier B, et al. PHOX2B genotype allows for prediction of tumor risk in congenital central hypoventilation syndrome. Am J Hum Genet 2005;76(3):421-426. 
9. van Limpt V, Schramm A, van Lakeman A, Sluis P, Chan A, van Noesel M, et al. The Phox2B homeobox gene is mutated in sporadic neuroblastomas. Oncogene 2004;23(57):92809288.

10. Bailleul-Forestier I, Molla M, Verloes A, Berdal A. The genetic basis of inherited anomalies of the teeth. Part 1: clinical and molecular aspects of non-syndromic dental disorders. Eur J Med Genet 2008;51(4):273-291.

11. Wang Y, Kong H, Mues G, D'Souza R. Msx 1 mutations: how do they cause tooth agenesis? J Dent Res 2011;90(3):311-316.

12. Revet I, Huizenga G, Chan A, Koster J, Volckmann R, van Sluis P, et al. The MSX1 homeobox transcription factor is a downstream target of PHOX2B and activates the DeltaNotch pathway in neuroblastoma. Exp Cell Res 2008;314(4):707-719.

13. Revet I, Huizenga G, Koster J, Volckmann R, van Sluis P, Versteeg R, et al. MSX1 induces the Wnt pathway antagonist genes DKK1, DKK2, DKK3, and SFRP1 in neuroblastoma cells, but does not block Wnt3 and Wnt5A signalling to DVL3. Cancer Lett 2010;289(2):195-207. 